\title{
Analysis of Aroma Compounds in Tofu from Lembang, Sumedang and Garut West Java, Indonesia
}

\author{
${ }^{1}$ Assyifa Junitasari \\ ${ }^{1}$ Chemistry Departement, Faculty of Science and Technology, UIN Sunan Gunung Djati \\ Bandung, J1. A.H. Nasution No. 105, Cipadung, Bandung 40614, Indonesia \\ Email Correspondence: assyifajunitasari@uinsgd.ac.id
}

\author{
Article Info \\ Article History \\ Received: 09 February \\ 2021 \\ Revised: 09 July 2021 \\ Published: 25 September \\ 2021 \\ Keywords \\ Tofu;GC-MS;Organoleptic \\ tests
}

\begin{abstract}
Tofu from Lembang, Tofu from Sumedang, and Tofu from Garut are three types of tofu that are produced in different places, but still close. Although made from the same raw material that is soy, every tofu will produce different tofu, both in terms of taste, aroma, texture, and suppleness. Differences in the type of flavor compounds used can also be a factor causing divergence of any tofu product.The characteristic of the tofu were determined by identifying the flavour compouds GC-MS, as well as organoleptic tests. To determine differences in compound-producing falvour in the tofu. The results extraction method was carried out on tofu samples using n-pentane as solvent then analyzed using GC-MS. Flavour compounds of all three types of tofu included into the ester group, alkenes and aldehydes. Organoleptic tests show that the panelists prefered. Tofu from Sumedang for test of colour appearance (82\%), for the test texture panelists like Tofu from Garut (83\%), for test of elasticity panelists prefered Tofu from Garut Lembang (75\%), for taste test panelists prefered Tofu from Lembang (88\%), panelists prefered Tofu from Lembang for flavour test $(82 \%)$.
\end{abstract}

(C) 2021 Science Education Study Program FKIP Unisla Lamongan West Java, Indonesia. Science Education and Application Journal. 3(2).

\section{INTRODUCTION}

The difference in bacterial survival in each whey was closely related to the aroma produced by-products that require whey as a coagulant, in this case cheese and tofu. This difference is due to differences in the metabolic activity of each bacterium, specifically, it's amino acid catabolism which will produce scented compounds (Marilley \& Casey, 2004).

The identification of scented compounds can be done using chromatographic techniques. Chromatographic techniques began to be known since 1834. The technique was introduced by Runge F.F. by using paper without glaze (glass coating) and / or pieces of fabric for testing spot (color spots) dyed and plant extracts (Grob, 2004). Chromatography according to Grob (2004) is a method of separating physical components of materials where the components are distributed into 2 phases, namely the stationary phase and the car phase. The stationary phase can be solid or liquid on a solid matrix.

Gas chromatography was first introduced by James and Martin in 1952 (James \& Martin in Kitson et al., 2002). According to Kitson et al. (2002) working principle of gas chromatography, in general, includes converting the sample phase to the gas phase by heating at the injection site, separating the specific mixture components in the prepared column and detecting each component using a detector.

According to Kitson et al. (2002) several key features that must be understood in the effective operation of a gas chromatogram include the heating system on the injector (sample 
intake system), the detector and the transfer rate and temperature programming in the chromatography column. The submission of a sample in a gas chromatograph requires the presence of a carrier gas as the mobile phase of the gas chromatograph. The commonly used carrier gas is helium, but gases such as hydrogen and nitrogen can also be used. The main requirement for the carrier gas is inert (does not react with samples). There are several sample entry techniques for gas chromatography analysis including gas sampling valves, split and splitless injection, on-column injection and programmed temperature injections (Kitson et al., 2002).

Mastuti and Handayani (2013) analyzed the aroma compounds on banana leaves using the GC-MS method. The resulting ethyl acetate extract of banana leaf was identified by its constituent compounds by GC-MS chromatography and analyzed descriptively. The results of the identification of chemical compounds from the two types of banana leaf water distillation extracted with ethyl acetate solvent showed the same compound namely 2Methoxy-4-vinyl phenol, Phytol, Vanillin, E-15-Heptadecenal, and 1,2-Benzenedicarboxylic acid, bis (2-Ethylhexyl) ester. The five compounds are thought to contribute to the aroma or flavor in both types of banana leaves. In addition to the five compounds, ambon banana leaves contain phenols, 2,4-bis (1,1-dimethyl ethyl) and Alloaromadendren which are thought to contribute to the flavor produced.

By using the High-Resolution Gas Chromatography-Mass Spectrometry (HRGS-MS) method, it can be identified the content of volatile compounds produced in Whey during the cheese or tofu clumping process, and the results are obtained that some compounds found in cheese or tofu are as follows: Acetic Acid, Ethyl Butanoate, Phenol, Methyl Disulfide, 1butanol (Mauriello et al., 2003).

\section{METHODS}

\section{Analysis of Aroma Producing Compounds with GC-MS}

The tofu sample was extracted by the soxhlet method using n-pentane solvent, separated again using a separating funnel, and GC-MS analysis was carried out under the conditions as shown in Table 1.

Table 1. GC-MS Regulatory Conditions

\begin{tabular}{ll}
\hline Condition & Information \\
\hline GC Conditions & \\
Brand & Shimadzu QP-5000 \\
Column & HP5 capillary column, length $30 \mathrm{~m}$, inner \\
& diameter $0.32 \mathrm{~mm}$, film thickness $0.25 \mu \mathrm{m}$ \\
& \\
Carrier Gas & Helium with a pressure of $40.40 \mathrm{Kpa}$ \\
Insterface & $230^{\circ} \mathrm{C}$ \\
temperature & $230^{\circ} \mathrm{C}$ \\
Injection Volume & $1 \mu \mathrm{L}$ \\
Volume Injeksi & 0.5 minutes \\
Sampling Time & $40^{\circ} \mathrm{C}$ is held for 5 minutes \\
Initial Temperature & $40^{\circ} \mathrm{C} /$ minute \\
Rate of Temperature & $225^{\circ} \mathrm{C}$ held for 5 minutes \\
Increase & \\
Final Temperature & \\
& \\
MS Conditions & $1.20 \mathrm{Kv}$ \\
Ionization Energy & $30-400$ \\
Mass Range & 0.5 minutes \\
\hline
\end{tabular}




\begin{tabular}{ll}
\hline Condition & Information \\
\hline Interval & 1000 \\
Resolution & $1.6-75.0$ minutes \\
Time & \\
\hline
\end{tabular}

\section{Organoleptic Analysis}

The organoleptic analysis was carried out on 20 unskilled panelists, as many as 11 women and 9 men who were students of the Chemical Education Study Program at UIN Sunan Gunung Djati Bandung which aimed to test the flavor of Lembang, Sumedang, and Garut and analyze differences in the aroma, taste, texture, color appearance and suppleness. Organoleptic results are presented in the questionnaire form.

\section{RESULTS AND DISCUSSION}

Tofu produced from different places namely Lembang, Sumedang and Garut have differences in terms of texture, elasticity, color and also taste as seen in Table 2.

Table 2. Physical Analysis of Lembang Tofu, Sumedang, Garut.

\begin{tabular}{llll}
\hline \multicolumn{1}{c}{ Variable } & \multicolumn{1}{c}{$\begin{array}{c}\text { Tofu from } \\
\text { Lembang }\end{array}$} & \multicolumn{1}{c}{$\begin{array}{c}\text { Tofu from } \\
\text { Sumedang }\end{array}$} & \multicolumn{1}{c}{$\begin{array}{c}\text { Tofu from } \\
\text { Garut }\end{array}$} \\
\hline $\begin{array}{l}\text { Texture } \\
\text { Colour }\end{array}$ & $\begin{array}{l}\text { Chewy } \\
\text { Slightly dull white } \\
\text { The flavour of soy } \\
\text { beans and milk } \\
\text { The taste of soy beans } \\
\text { and milk }\end{array}$ & $\begin{array}{l}\text { Mushy/soft } \\
\text { White }\end{array}$ & $\begin{array}{l}\text { Crusty } \\
\text { White }\end{array}$ \\
& $\begin{array}{l}\text { The flavour of soy } \\
\text { beans and acid } \\
\text { The }\end{array}$ & $\begin{array}{l}\text { The flavour of soy beans } \\
\text { and little acid }\end{array}$ & $\begin{array}{l}\text { The flavour of soy beans } \\
\text { The ans and acid } \\
\text { and acid } \\
\text { The flavour of soy beans } \\
\text { and little acid }\end{array}$ \\
\hline
\end{tabular}

The difference in tofu products from the three places was allegedly due to differences in microorganisms involved during the tofu making process, differences in treatment during the tofu making process and could be caused by differences in the coagulant used as well as components of aroma compounds. In this section, the results of research on aroma analysis and organoleptic analysis will be presented.

\section{Analysis of Aroma Compounds}

Analysis of aroma compounds by GC-MS method was carried out to determine differences in compounds produced in Lembang Tofu, Sumedang and Garut which aims to get one of the reasons for differences in taste, especially aroma in Lembang, Sumedang, and Garut Tofu. Aroma compound analysis was performed by tofu extraction with a soxhlet method using n-pentane solvent, separated using separating funnel, and GC-MS analysis. Chromatogram results showed a peak difference that was seen in the three types of samples, namely tofu Lembang, Sumedang and Garut. GC-MS chromatogram results can be seen in Figure. 
8
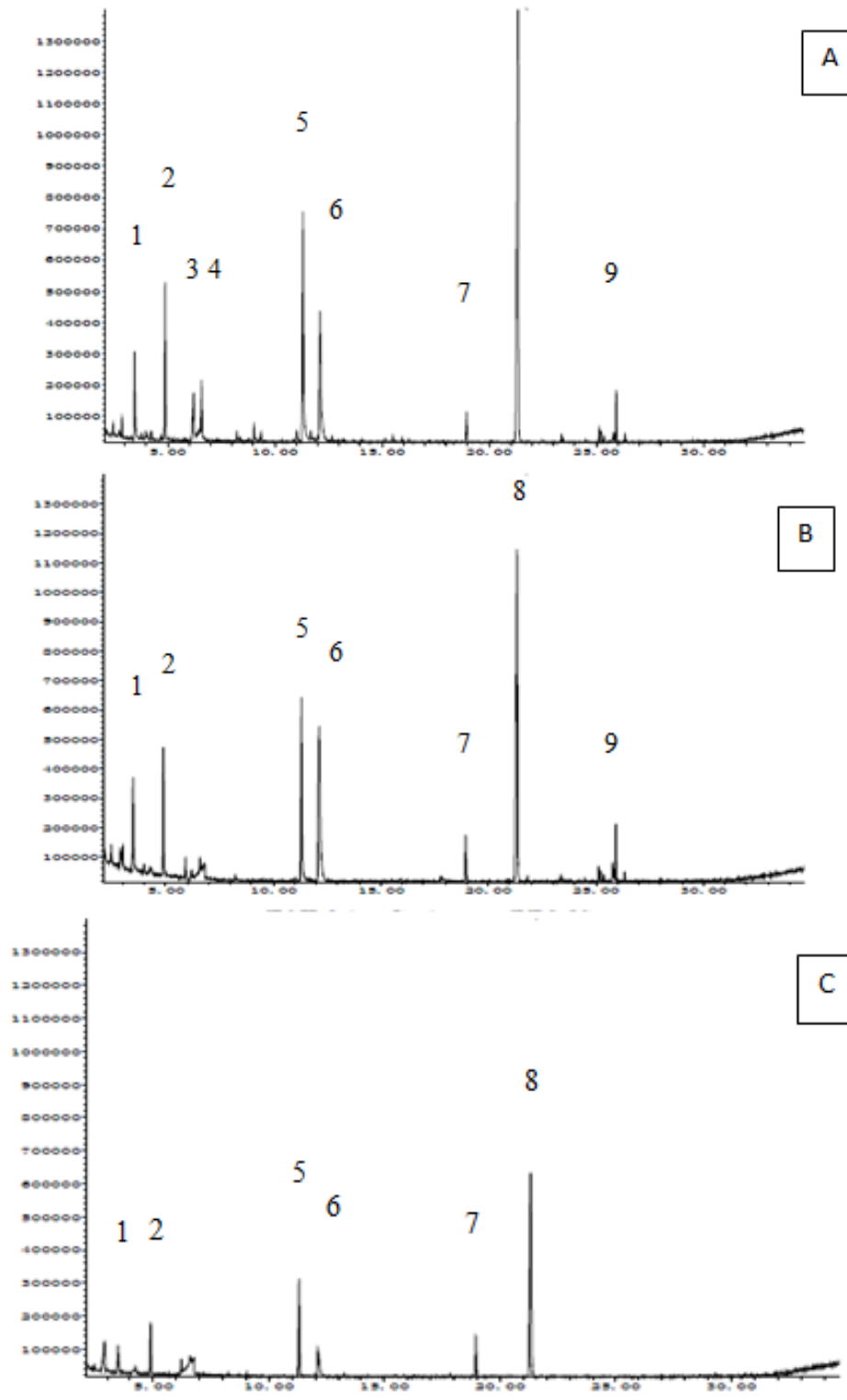

Figure 1. Results of GC1 MS Chromatogram on Tofu Lembang (A), Tofu Sumedang (B), Tofu Garut (C)

The identification of aroma constituent compounds was carried out using the Library database: WILLEY09TH.L (Ong et al., 1998). The compounds that have been identified are likely to be aromas of tofu.

Based on the identification of GC-MS chromatogram peaks with the Library: WILLEY09TH.L database shown in Table 1 that the 1 st peak of the three samples showed that there were acetic acid compounds, this shows that the aroma and taste found in tofu, probably caused by acetic acid compounds because of the type of coagulant some know uses acetic acid as its coagulant. The second peak was found in all three samples. The results of the identification of the 2nd peak showed that the compound was ethyl butanoate. The 3rd bud identified as 3-methyl-1-butyl acetate compound was only found in Lembang Tofu samples, this shows that only microorganisms found in Lembang Tofu whey could produce the compound. The 4th peak which shows the limonene compound is also only found in the Lembang Tofu sample. The 5th peak shows the phenol compound, the 6th peak shows ethyl acetate compound, the 7th peak shows the methyl disulfide compound and the 8th peak 
shows 1-butanol compound found in all samples. This shows that all microorganisms contained in all three samples can produce these compounds. Unlike the case with the 9th peak that was identified as a benzaldehyde compound only found in the sample of Lembang and Sumedang Tofu, the Tofu Garut 9th peak did not appear. This shows that the microorganism whey Know Garut cannot produce these compounds.

Based on the differences from each GC-MS chromatogram results, it can be seen that the microorganisms found in the Lembang Tahu whey can produce more varied aromaproducing compounds than the microorganisms in the Sumedang and Garut Tahu whey.

Microorganisms in Sumedang and Garut Tofu whey which has a close enough kinship, are unable to produce 3-methyl-1-butyl acetate and limonene compounds like those produced by microorganisms in Tofu Lembang whey. These results further support the hypothesis that the type of microorganism determines the characteristics of the tofu produced.

The difference in the resulting compound can affect the aroma of the three types of tofu. The differences in aldehydes, esters and alkenes indicate different scents.

Table 3. Analysis of volatile compounds resulting from GC-MS chromatograms

\begin{tabular}{cccccc}
\hline $\begin{array}{c}\text { Peak } \\
\text { L }\end{array}$ & $\begin{array}{c}\text { Peak } \\
\text { S }\end{array}$ & $\begin{array}{c}\text { Peak } \\
\text { G }\end{array}$ & RT & $\begin{array}{c}\text { Peak Area } \\
(\mathbf{\%})\end{array}$ & Volatil \\
\hline $\mathbf{1}$ & 1 & 1 & 3.48 & 3.22 & Asetic Acid \\
$\mathbf{2}$ & 2 & 2 & 5.03 & 3.51 & Ethyl Acetate \\
$\mathbf{3}$ & - & - & 6.77 & 0.19 & Ethyl Butanoat \\
$\mathbf{4}$ & - & - & 6.98 & 0.14 & 3-Methyl-1-ButylAcetate \\
$\mathbf{5}$ & 5 & 5 & 12.36 & 11.68 & Benzaldehyde \\
$\mathbf{6}$ & 6 & 6 & 13.02 & 0.67 & Phenol \\
$\mathbf{7}$ & 7 & 7 & 19.87 & 0.19 & 1-Butanol \\
$\mathbf{8}$ & 8 & 8 & 23.74 & 3.92 & Dimethyl Disulfide \\
$\mathbf{9}$ & 9 & - & 26.63 & 0.73 & Limonene \\
\hline
\end{tabular}

\section{Organoleptic Analysis}

To strengthen the different characteristics of the three years, organoleptic tests were carried out. Organoleptic test conducted by 20 unskilled panelists, this organoleptic test shows the level of panelists' preference for color, aroma, taste, texture and elasticity. The results of the organoleptic analysis can be seen in Figure.

The organoleptic test shows that the color appearance test favored by panelists is Sumedang Tofu by $82 \%$, texture test which is preferred by panelists by $83 \%$ is Garut Tofu, the elasticity test that panelists prefer is $75 \%$ is Lembang Tofu, a taste test is preferred by 88 $\%$ is Tofu Lembang, the aroma test that panelists prefer is $82 \%$ is Tofu Lembang.

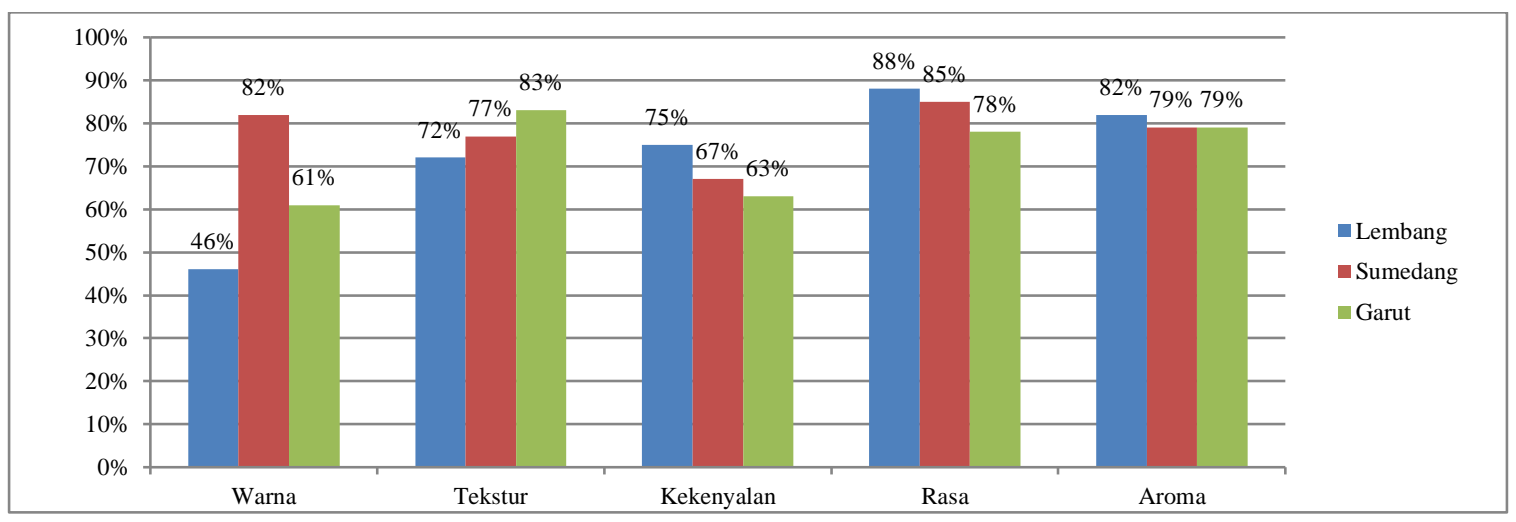

Figure 2. Results of organoleptic analysis 
After analyzing to see differences in the response of panelists to each organoleptic test results on the sample shows that for the panelist color test gives a preference value with an average result quite different for each sample, for the panelist test the texture gives a preference value with an average result different sample mean, for panelist elasticity test gives preference value with different average results for each sample, for panelist taste test gives preference value with different average results for each sample, but for panelist aroma test gives value Preference with the average sample results are almost the same, this is probably due to the aroma in each type of tofu containing the same aroma dominance so that panelists find it difficult to distinguish the scents from the three samples.

Organoleptic test results showed that the panelists preferred flavor of Lembang Tofu, it was probably caused by the aroma-producing compounds from Tofu Lembang more varied.

\section{CONCLUSION}

Fragrance compounds of three different types of Tofu, the presence of esters, alkenes and aldehydes affect the aroma of Tofu. Microorganisms found in whey tofu affect the characteristics of the tofu produced.

The organoleptic test shows that the color display test that panelists prefer is Sumedang Tofu by $82 \%$, texture test which panelists prefer is $83 \%$ is Garut Tofu, Toughness test which panelists prefer $75 \%$ is Lembang Tofu, a taste test is preferred by $88 \%$ is Tofu Lembang, the Aroma test which is preferred panel is $82 \%$ is Tofu Lembang. The conclusion of the research is presented briefly, narrative, non-bulleted, and conceptual. The research impact must be stated.

\section{REFERENCES}

Abe, T., Sugawara, H., Kinouchi, M., dan Kanaya, S. (2005): Novel Phylogenetic Studies of Genomic Sequence Fragments Derived from Uncultured Microbe Mixtures in Environmental and Clinical Samples, DNA Research, 12, 281-290

Altschul, S.F., Madden, T.L., Schaffer, A.A., Zhang, Z., Miller, W., dan Lipman, D.J. (1997): Gapped BLAST and PSI-BLAST, a new generation of protein database search programs, Nucleic Acids Research, 25, 3389-3402

Amann, R.I. (1995): Fluorescently labelled, rRNA-targetted oligonucleotide probes in the study of microbial ecology, Molecular Ecology, 4, 543-554

Aminin, A.L.N. (2008): Biodiversitas Bakteri Termofilik Sumber Air Panas Gedongsongo Jawa Tengah, Disertasi Program Doktor, Institut Teknologi Bandung

Aryantha, I.N.P. (2005): Strategi Riset dan Pengembangan dalam Pengelolaan Potensi Biodiversitas dalam Workshop Pengelolaan Potensi Biodiversitas, LPIU-FK8PTUniversitas Udayana, Kampus Bukti Jimbaran, Denpasar, Bali

Bassam, B.J., Anolles, C.G. dan Greshoff, P.M. (1991): Fast and sensitive staining of DNA in polyacrylamide gels, Analytical Biochemistry, 196, 80-83

Blackwood, C.B., Marsh, T., Kim, S.H., dan Paul, E.A. (2003): Terminal restriction fragment length polymorphism data analysis for quantitative comparison of microbial communities, Applied and Environmental Microbiology, 69, 926-932

Blake, R.D., dan Delcourt, S.G., (1996): Thermodynamic effects of formamide on DNA stability, Nucleic Acids Research, 24, 2095-2103

Bruce, K. (1997): Analysis of mer gene subclasses within bacterial communities in soils and sediments resolved by fluorescent PCR Restriction fragmenr length polymorphism profiling, Applied and Environmental Microbiology, 63, 4914-4919

Champagne, C.P., Johnson, J.G., Raymond, Y., Barrette, J. dan Buckley, N. (2009): Selection of Probiotic Bacteria for the fermentation of a Soy Beverage in Combination with Streptococcus thermophilus, Food Research International, 42 (5-6), 612-621 
Clarridge III, J.E. (2004): Impact of 16S rRNA Gene Sequence Anlysis for Identification of Bacteria on Clinical Microbiology and Infectious Diseases, Clinical Microbiology Reviews, 17 (4), 840-862

DeLong, E.F. dan Pace, N.J. (2001): Environmental diversity of Bacteria and Archea. Systematics Biology, 50, 470-478

Dojka, M.A., Hugenholtz, P., Haack, S.K., dan Pace, N.R. (1998): Microbial Diversity in a Hydrocarbon and Chlorinated Solvent Contaminated Aquifer Undergoing Intrinsic Bioremediation, Applied and Enviromental Microbiology, 64, 3869-3877

Doolittle, W.F. (1999): Phylogenetic Classification and the Universal Tree, Science, 284, 2124-2128

Dunbar, J., Ticknor, L.O., dan Kuske, C.R. (2000): Assessment of Microbial Diversity in Four Southwestern United States Soils by 16S rRNA Gene Terminal Restriction Fragment Analysis, Applied and Environmental Microbiology, 66, 2943-2950

Efron, B., Halloran, E., dan Holmes, S. (1996): Boostrap confidence levels for phylogenetic trees, Proceeding of the National Academy of Sciences, U.S.A, 93

Fatha, A. (2007): Pemanfaatan Zeolit Aktif Untuk Menurunkan BOP dan COD Limbah Tahu. Semarang. Universitas Negeri Semarang

Felsenstein, J. (1993): PHYLIP-phylogeny interference package (version 3.5), Cladistics, 5, 164-166

Ferris, M.J., Muyzer, G., dan Ward, D.M. (1996): Denaturing Gradient Gel Electrophoresis Profiles of $16 \mathrm{~S}$ rRNA Defined Populations Inhabiting a Hot Spring Microbial Mat Community, Applied and Environmental Microbiology, 63, 340-346

Fischer, S.G., dan Lerman, L.S. (1983): DNA fragments differing by single base pair substitutions are separated in denaturing gradient gels, Correspondence with melting theory, Proceeding of the National Academy of Sciences, U.S.A, 80, 1579-1583

Fox, G.E., Stackebrandt, E., dan Hespell, R.B. (1980): The phylogeny of prokaryotes, Science, 25, 457-463

Giovanonni, S.J., Britschgi, T.B., Moyer, C.L. dan Field, K.G. (1990): Genetic diversity in Sargasso Sea bacterioplankton, Nature, 345, 60-63

Hawksworth, D.L., (2001): The Magnitude og Fungal Diversity : The 1,5 Million Species Estimate Revisited. Mycoplasma Research, 105(12), 1422-1432

Hayes, V.M., Wu, Y., Osinga, J., Mulder, I.M., van der Vlies, P., Elfferich, P., Buys, C.H.C.M., dan Hofstra, R.M.W. (1999): Improvements in Gel Composition and Electrophoretic Conditions for Broad Range Mutation Analysis by Denaturing Gradient Gel Electrophoresis, Nucleic Acids Reearch, 27, e29

Huber, R., Huber, H., dan Stetter, K.O. (2000): Towards the ecology of hyperthermophilic, biotopes, new isolation stategies and novel metabolic properties, FEMS Microbiology Reviews, 24, 615-623 